\title{
Recommendations for False Negative Covid-19 PCR Tests Patients
}

\section{Benabdellah $\mathrm{A}^{1 *}$, Brahimi $\mathrm{H}^{1}$, Badla $\mathrm{Y}^{1}$, Benabdellah $\mathrm{Y}^{2}$ and Labdouni $\mathrm{MH}^{2}$}

${ }^{1}$ Faculty of Medicine, University Abou Bekr Belkaid, Tlemcen, Algeria

${ }^{2}$ University of Oran 1, Oran, Algeria

*Corresponding Author: Benabdellah A, Faculty of Medicine, University Abou Bekr Belkaid, Tlemcen, Algeria.
Received: September 22, 2020

Published: November 18, 2020

(C) All rights are reserved by Benabdellah A., et al.

\section{Abstract}

The current Covid-19 pandemic imposes a diagnostic strategy for the care of patients. The sensitivity for the Covid-19 PCR is 56 to $83 \%$. A single negative test can rule out Covid-19 in the majority of situations. However, since the negative predictive value of the test is between 88 and 95\%, it is essential to ensure the follow-up of these patients. For those with typical symptoms, a negative test should be interpreted with caution and a second test may be indicated.

Keywords: Covid-19; PCR; False Negative Covid-19

\section{Introduction}

In the context of the Covid-19 pandemic, the number of patients and deaths is increasing very rapidly in Algeria and worldwide. The evaluation of the diagnostic characteristics of the nasopharyngeal smear-PCR is important for the management of patients. The probability of being detected positive is linked to the viral load and depends on the duration of the symptoms and the severity of the disease.

Several studies have evaluated the properties of the nasopharyngeal smear-PCR in comparison with radiological examinations. The quality of the studies concerning the sensitivity is low and the details on the characteristics of the patients and the gold standard used are poor.

From the available bibliographic data, the sensitivity can be estimated between 56 and 83\% [1-4].

\section{Current situation}

The current literature regarding the performance of the Covid-19 PCR contains low quality studies.

As long as the test was performed as recommended, we believe the negative predictive value (NPV) is high enough to rule out a Covid-19. However, since it is between 88 and 95\%, it is essential to ensure the follow-up of these patients.

In a patient who cumulates several typical symptoms, a negative test should be interpreted with caution and a second test may be indicated.

\section{Recommendations}

A single negative test will rule out a Covid-19 in most situations. In these situations, a negative test should be interpreted with caution. It is essential to ensure the follow-up of these patients (NPV 88 to $95 \%$ ) and to recommend them strict self-isolation, according to the recommendations in force for Covid. A second test may be indicated in a patient who cumulates several typical symptoms.

\section{Conclusion}

In conclusion, a negative Covid-19 PCR test should be evaluated and should be interpreted with caution, and self-isolation is indicated for any patient with typical symptoms of virosis. A second test may be indicated for the patient who has several typical symptoms of Covid-19. 


\section{Bibliography}

1. Wang W., et al. "Detection of SARS-CoV-2 in different types of clinical specimens". The Journal of the American Medical Association (2020).

2. Hong Kh., et al. "Evaluating the accuracy of different respiratory specimens in the laboratory diagnosis and monitoring the viral shedding of 2019-nCoV infections. Guidelines for laboratory diagnosis of coronavirus disease 2019(COVID-19) in Korea". Annals of Laboratory Medicine 40.5 (2020): 351-360.

3. Arevalo-Rodriguez I., et al. "False-negative results of initial RTPCR assays for COVId-19:a systematic review (2020).

4. Woloshin S., et al. "False-negative tests for SARS-CoV-2 infection-challenges and implications". The New England Journal of Medicine 383.6 (2020): e38.

\section{Assets from publication with us}

- Prompt Acknowledgement after receiving the article

- Thorough Double blinded peer review

- Rapid Publication

- Issue of Publication Certificate

- High visibility of your Published work

Website: www.actascientific.com/

Submit Article: www.actascientific.com/submission.php

Email us: editor@actascientific.com

Contact us: +919182824667 